\title{
Electrocoagulation of Palm Oil Mill Effluent
}

\author{
Melissa B. Agustin ${ }^{1,2}$, Waya P. Sengpracha ${ }^{3 *}$ and Weerachai Phutdhawong ${ }^{4 *}$ \\ ${ }^{1}$ Dept. of Chemistry, Faculty of Science, Maejo University, Sansai, Chiang Mai 50290, Thailand \\ ${ }^{2}$ Dept. of Chemistry, College of Arts and Sciences, Central Luzon State University, Science City of Muñoz, Nueva Ecija, 3120 , \\ Philippines \\ ${ }^{3}$ Dept. of Chemistry, Faculty of Science, Silpakorn University, Nakhon Pathom 73000, Thailand \\ ${ }^{4}$ Dept. of Science, Faculty of Liberal Arts and Science, Kasetsart University, Kamphaeng Saen, Nakorn Pathom 73140, Thailand. \\ *Correspondence to Dr. Weerachai Phutdhawong and Dr. Waya P. Sengpracha. E-mail: weerachai.p@ku.ac.th or \\ phutdhawong@gmail.com and sengwaya@su.ac.th
}

Received: 20 February 2008 / Accepted: 21 March 2008 / Published: 30 September 2008

\begin{abstract}
Electrocoagulation (EC) is an electrochemical technique which has been employed in the treatment of various kinds of wastewater. In this work the potential use of EC for the treatment of palm oil mill effluent (POME) was investigated. In a laboratory scale, POME from a factory site in Chumporn Province (Thailand) was subjected to EC using aluminum as electrodes and sodium chloride as supporting electrolyte. Results show that EC can reduce the turbidity, acidity, COD, and BOD of the POME as well as some of its heavy metal contents. Phenolic compounds are also removed from the effluent. Recovery techniques were employed in the coagulated fraction and the recovered compounds was analysed for antioxidant activity by DPPH method. The isolate was found to have a moderate antioxidant activity. From this investigation, it can be concluded that EC is an efficient method for the treatment of POME.
\end{abstract}

Keywords: POME treatment; Electrocoagulation, Phenolic compound

\section{Introduction}

Palm oil mill effluent (POME) is an important source of inland water pollution when released without treatment into local rivers or lakes. POME has generally been treated by anaerobic digestion, resulting in methane as a value-added product [1,2]. Many methods have been reported in the literature regarding the treatment of POME such as treatment using a pond system [3] and aerobic digestion of POME to decrease carbon content and inorganic nitrogen with consequent change of $\mathrm{pH}$ from the acidic range to an alkaline one [4]. Other treatments include one that increases the ratio of organic nitrogen, leading to the production of a better fertilizer [4], a pretreatment using Moringa oleifera seeds as an environmentally friendly coagulant [5], a treatment in an up-flow anaerobic sludge fixed film bioreactor [6], an upflow anaerobic sludge fixed film bioreactor using response surface methodology (RSM) [7], methane emission from anaerobic ponds [8], semi-commercial closed anaerobic digester [9] and by synthetic polyelectrolytes [10]. As far as we know, electrocoagulation (EC) has not yet been reported as a treatment for palm oil mill effluent. In this study, EC, a distinctly economical and an environmentally-friendly choice for meeting wastewater discharge standards is reported as an alternative method for POME treatment. Moreover, in this investigation, the coagulum was recovered and the antioxidant activity of the isolate was determined.

\section{Materials and Methods}

\section{Materials}

The palm oil mill effluent used in this study was collected at Chumporn Palm Industries, Chumporn, Thailand.

\section{Electrocoagulation of POME and Isolation of Potential} Antioxidant

Prior to EC, residual oil in POME was rid of by extracting with hexane in a separatory funnel. One litre of the de-oiled POME was then transferred to a glass 
cylindrical vessel (inner diameter: $12 \mathrm{~cm}$, height: $23 \mathrm{~cm}$ ) with a special cover to support a pair of aluminium electrodes having a dimension of $30 \mathrm{~cm} \times 10 \mathrm{~cm} \times 1 \mathrm{~mm}$. Sodium chloride $(2.0 \mathrm{~g})$ was added to the solution as supporting electrolyte. The electrodes were immersed 4 $\mathrm{cm}$ apart and $8 \mathrm{~cm}$ deep into the solution which was kept stirred throughout the experiment. Crotech (Model ZT3202) was used to supply the solution with a direct current (1.4-2.0 A, 3.50-12V). Electrocoagulation was continued for a total of $6 \mathrm{hrs}$ excluding the time consumed for replacing the electrodes every hour. After the electrolytic process, the solution was filtered using vacuum filtration. The clear filtrate $(370 \mathrm{ml})$ obtained-the effluent after EC- was kept in a glass bottle and stored in the refrigerator for analysis and the coagulum was collected and dried in an oven at $40^{\circ} \mathrm{C}$. The dried coagulum was pulverised and dissolved with $7 \% \mathrm{HCl}$ in the ratio of $1 \mathrm{~g}$ coagulum: $5 \mathrm{ml}$ acid. The acid-coagulum mixture was kept stirred to ensure complete dissolution and was then transferred to a separatory funnel. An equal volume of 1-butanol (n-BuOH) was added and the mixture was shaken vigorously and allowed to separate overnight. The $\mathrm{n}-\mathrm{BuOH}$ extract was collected and the remaining aqueous solution was further extracted with $\mathrm{n}-\mathrm{BuOH}$ twice. All the n-BuOH extracts were combined and washed with water three times to remove any trace of inorganic compounds from the aqueous layer. The n$\mathrm{BuOH}$ was removed using vacuum rota-evaporation which enabled the recovery of the solvent. The residual compounds (presumably containing mainly the phenolic compounds from POME) were further dried at $40^{\circ} \mathrm{C}$ in an oven.

\section{$\mathrm{COD}$ and $\mathrm{BOD}_{5}$ Determination}

$\mathrm{COD}$ and $\mathrm{BOD}_{5}$ of the palm oil mill effluent before and after EC were determined according to the Standard Methods for Examination of Water and Wastewater [11]. COD was analyzed using the closed reflux titrimetric method. Briefly, the method involves refluxing a known volume of sample with an oxidizing agent $\left(\mathrm{K}_{2} \mathrm{Cr}_{2} \mathrm{O}_{7} / \mathrm{H}-\right.$ ${ }_{2} \mathrm{SO}_{4}$ ) in a closed ampule at $150{ }^{\circ} \mathrm{C}$ for two hours, and titrating the excess oxidizing agent with standard ferrous ammonium sulfate using ferroin as indicator. $\mathrm{BOD}_{5}$ determination involves filling with sample, to overflowing, a BOD bottle of the specified size and incubating it at $20^{\circ} \mathrm{C}$ for 5 days. Dissolved oxygen (DO) is measured initially and after incubation using titrimetric method and the BOD is computed from the difference between the initial and final DO. All determinations were done in duplicate.

\section{Metal Analysis}

The concentrations of the following metals: $\mathrm{Cu}, \mathrm{Cr}$, $\mathrm{Mn}, \mathrm{Fe}$ and $\mathrm{Pb}$ in the POME before and after EC were analyzed in the filtered samples using Flame-Atomic Absorption Spectrophotometry (Perkin Elmer Analyst 100). The detection limit was estimated as the standard deviation of the concentrations of blank samples multiplied by three.

DPPH Free Radical Scavenging Assay of the POME Isolate

Solutions of the POME isolate containing mainly the recovered phenolic compounds were prepared at varying concentrations $(1000,500,250,100,50 \mathrm{ppm})$ in methanol. $0.20 \mu \mathrm{M} \quad$ 1,1-Diphenyl-2-picrylhydrazyl (DPPH) methanolic solution $(3 \mathrm{~mL})$ were added to the POME isolate solution $(1 \mathrm{~mL})$. For blank analysis, $\mathrm{MeOH}(1 \mathrm{~mL})$ was used. The decrease in concentration of DPPH as a measure of antioxidant activity was measured via UV-Vis spectrophotometer (ThermoSpectronic) at $517 \mathrm{~nm}$. The antioxidant activity was compared with a standard solution of Vitamin E.

\section{Results and Discussion}

Electrocoagulation of POME and Isolation of Possible Phenolic Antioxidant

Table 1 shows the comparison of POME before and after EC. Electrocoagulation of the POME afforded a clear solution from a dark brown, opaque effluent (Figure 1).

Table 1: Comparison of POME solutions before and after 6-hour electrocoagulation

\begin{tabular}{lcr}
\hline $\begin{array}{l}\text { Properties/ } \\
\text { Test }\end{array}$ & Before EC & After EC \\
\hline Color & Dark brown & Pale yellow \\
Turbidity & Opaque & Transparent (clear) \\
$\mathrm{pH}$ & 4.30 & 7.63 \\
$\mathrm{FeCl}_{3}$ test & Positive & Negative \\
$\mathrm{COD}$ & $36,800 \pm 283 \mathrm{mgL}^{-1}$ & $25,600 \pm 354 \mathrm{mgL}^{-1}$ \\
$\mathrm{BOD}_{5}$ & $23,400 \pm 848 \mathrm{mLL}^{-1}$ & $14,400 \pm 1272 \mathrm{mgL}^{-1}$ \\
\hline
\end{tabular}

The $\mathrm{pH}$ of the solution also increased from 4.30 to 7.63 after EC. This could be explained by the formation of aluminium hydroxyl ions according to the following reactions.

Anode reaction: $\quad \mathrm{Al} \rightarrow \mathrm{Al}^{3+}+3 \mathrm{e}^{-}$

Cathode reaction: $\quad 2 \mathrm{H}_{2} \mathrm{O}+2 \mathrm{e}^{-} \rightarrow 2 \mathrm{OH}^{-}+\mathrm{H}_{2}$ Overall reaction: $\quad 2 \mathrm{Al}+6 \mathrm{H}_{2} \mathrm{O} \rightarrow 2 \mathrm{Al}(\mathrm{OH})_{3}+3 \mathrm{H}_{2}$

The aluminium can either react directly to an organic compound that contains negatively charged atoms, or form polymeric $\mathrm{Al}^{+3}$ hydroxo complexes, eg. aluminium hydroxide $\left[\mathrm{Al}(\mathrm{OH})_{3}\right]$, that can remove pollutants by adsorption to produce charge neutralization and by enmeshment in a precipitate or coagulum [12]. 


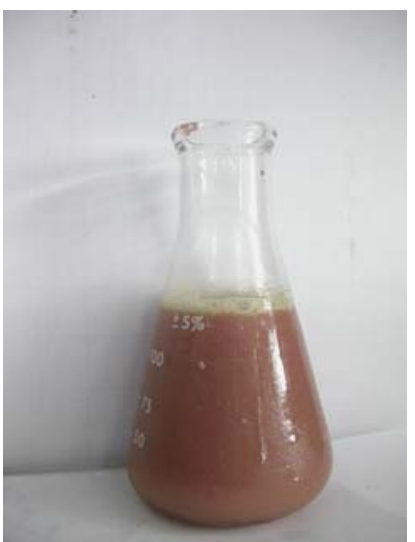

A

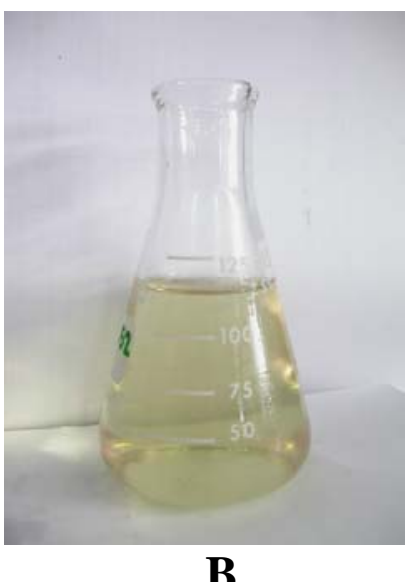

B
Figure 1: POME before (A) and after (B) electrocoagulation.

Before EC, the presence of phenolic groups in the POME was confirmed by the formation of a black-blue solution after the $\mathrm{FeCl}_{3}$ test. After EC, the reaction of the POME solution with the $\mathrm{FeCl}_{3}$ test gave a negative result (clear solution). With this simple test, it was demonstrated that the phenolic substances present in the effluent were virtually removed after EC, presumably mainly by complexation with aluminium ion and subsequent precipitation [13].

The partial removal of dissolved organic substances from POME was also confirmed by the decrease in chemical oxygen demand (COD) and biochemical oxygen demand in a 5-d test period $\left(\mathrm{BOD}_{5}\right)$ after EC. The mean values for $\mathrm{COD}$ and $\mathrm{BOD}_{5}$ before and after $\mathrm{EC}$ were significantly different at $95 \%$ confidence level. The mean COD level in POME before EC was $36,800 \mathrm{mgL}^{-1}$ which was reduced to $25,600 \mathrm{mgL}^{-1}$, corresponding to a $30 \%$ removal. $\mathrm{BOD}_{5}$ reduced from $23,400 \mathrm{mgL}^{-1}$ to 14,400 $\mathrm{mgL}^{-1}(38 \%$ removal). The observed percentages of removal for $\mathrm{COD}$ and $\mathrm{BOD}_{5}$ from this study were lower than that determined by the study of Ugurlu et al. [14] in the electrocoagulation of paper mill effluent which registered 75 and $70 \%$ removal of $\mathrm{COD}$ and $\mathrm{BOD}$, respectively. However, it has to be noted that in that study the initial COD and BOD levels of the paper mill effluent were approximately 86 and 900 times lower, respectively, than the initial COD and BOD of POME. It is also interesting to note that the averaged COD and BOD of POME before and after EC were significantly different at $95 \%$ confidence level. The removal of COD and BOD by electrocoagulation could be attributed to the removal of suspended solids and to precipitation of dissolved organic molecules as organometallic compounds [14]. Dissolution of the coagulum from a liter of POME followed by extraction afforded 17.1 grams of a black, flaky isolate that was tested for its antioxidant activity.

Presented in Table 2 is the change in the concentration of some representative common heavy metals analyzed in POME before and after EC. From this result, it is evident that $\mathrm{EC}$ can remove not only the organic constituents in the effluent, but also the inorganic contents like heavy metals, in agreement with many previous findings relating to EC [15].

Table 2: Metal content of POME before and after EC

\begin{tabular}{lccr} 
Metals & Before EC (ppm) & After EC (ppm) & $\begin{array}{r}\text { Detection } \\
\text { Limit (ppm) }\end{array}$ \\
\hline $\mathrm{Cu}$ & $\mathrm{nd}$ & $\mathrm{nd}$ & 0.027 \\
$\mathrm{Cr}$ & $0.059 \pm 0.01$ & $\mathrm{nd}$ & 0.036 \\
$\mathrm{Fe}$ & $40.57 \pm 0.06$ & $0.008 \pm 0.001$ & - \\
$\mathrm{Mn}$ & $10.44 \pm 0.02$ & $\mathrm{nd}$ & 0.042 \\
$\mathrm{~Pb}$ & $\mathrm{nd}$ & $\mathrm{nd}$ & 0.366 \\
\hline $\mathrm{nd}-$ not detected & &
\end{tabular}

\section{DPPH Antioxidant Test}

As reported in the prior discussion, some organic compounds including phenolic substances were removed during EC. With the assumption that these phenolic substances were successfully recovered from the coagulum through the isolation techniques employed in this study and in light of the known fact that phenolic compounds are good antioxidants, the POME isolate was tested for its antioxidant activity. The antioxidant activity of the POME isolate was determined by its ability to reduce the activity of the stable free radical diphenylpicrylhydrazyl (DPPH) and was compared with Vitamin E, a known antioxidant. It can be seen from Figure 2 that the absorbance of the DPPH radical solution decreased with increasing concentration of the POME isolate. However, the decrease in absorbance for the POME isolate did not match that of the Vitamin E. From the absorbance values, the percentage reduction was calculated using the equation:

$$
\% \text { reduction }=\frac{A_{b}-A_{s}}{A_{b}} \times 100
$$

where $A_{b}$ is the absorbance of the blank solution and $\mathrm{A}_{\mathrm{s}}$ is the absorbance of the sample.

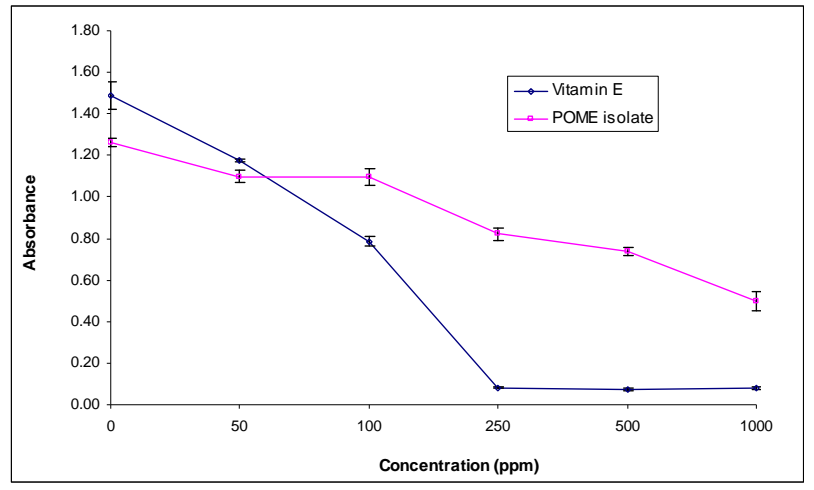

Figure 2: Absorbance values of the DPPH radical solution against the concentration of antioxidant. 
Shown in Figure 3 is the plot of the percentage reduction in DPPH radical at various concentrations of antioxidant. The POME isolate gave only $60.34 \%$ reduction at $1000 \mathrm{ppm}$ concentration, while Vitamin $\mathrm{E}$ gave $94.68 \%$ at the same concentration. Calculation of the equation of the line for each curve enabled the determination of the $\mathrm{EC}_{50}$, the effective concentration of the antioxidant at which $50 \%$ of the activity of the DPPH radical has been reduced. For Vitamin E, the $\mathrm{EC}_{50}$ was determined to be $106 \mathrm{ppm}$ while that of the POME isolate was 723ppm. The antioxidant activity of the POME isolate could possibly be increased by further purification.

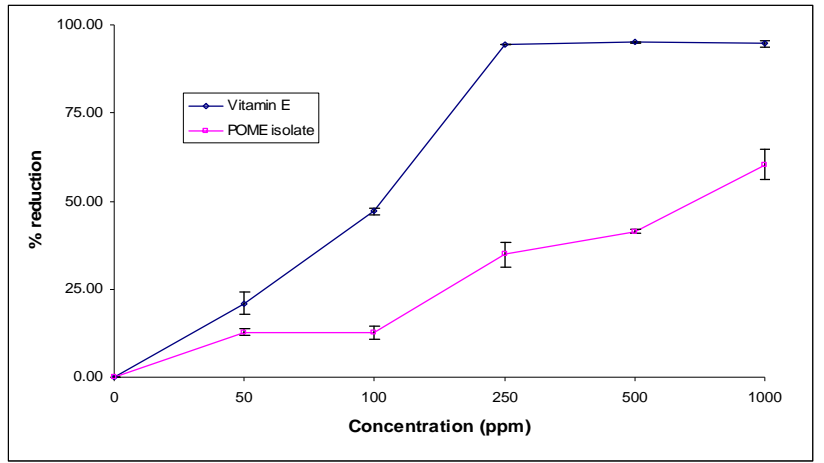

Figure 3: The percentage reduction in the activity of DPPH radical against the concentration of antioxidant.

\section{Conclusions}

It can be concluded from this study that EC can be a useful method for the treatment of palm oil mill effluent. EC enabled the removal of suspended solids, dissolved organic substances and some heavy metals in, and reduced the acidity, COD and BOD of the effluent. However, to obtain a higher percentage removal for COD and BOD, further study on optimization of the method is encouraged. The isolated organic compounds after recovering from the coagulum exhibited antioxidant activity which is lower than that of Vitamin E. The possibility of using the isolate as antioxidant for natural rubber could be of interest for future studies.

Acknowledgements: The authors gratefully acknowledge the financial support from Thailand Research Fund (RDG4850071 and MRG495S054). Dr. T. Cheunbarn's research group from Maejo University was acknowledged for COD and BOD facilities.

\section{References}

1. Sinnappa, S.: Studies of Palm Oil mill Waste Effluent. Malay. Agric. J. 1978, 51, 261-272.

2. Borja, R.; Banks, C. J.; Martin, A.; Khalfauoi, B.: Anaerobic digestion of Palm Oil Mill Effluent and Condensation Water Wastes: An Overall Kinetic Model for Methane Production and Substrate Utilization. Bioprocess Engin., 1995, 13, 87-95.
3. Chigusa, K.; Hasegawa, T.; Yamamota, N.; Watanabe, Y.: Treatment of Waste Water from Oil Manufacture Plant by Yeasts. Water Sci. Technol. 1996, 34, 51-58.

4. Agamuthu, P.; Tan, E. L.; Shaifal, A. A.: Effect of Aeration and Soil Inoculum on the Composition of Palm Oil Effluent (POME). Agric. Wastes, 1986, 15, 121-132.

5. Bhatia, S.; Othman, Z.; Ahmad, A. L.: Palm Oil Mill Effluent Pretreatment Using Moringa Ooleifera Seeds as an Environmentally Friendly Coagulant: Laboratory And Pilot Plant Studies. J. Chem. Technol. Biotechnol.. 2006, 81, 1852-1858.

6. Lorestani, A. A. Z.; Mohamed, A. R.; Mashitah, M. D.; Abdullah, A. Z.; Hasnain Isa, M.: Effects of Organic Loading Rate on Palm Oil Mill Effluent Treatment in an Up-Flow Anaerobic Sludge Fixed Film Bioreactor. Environ. Engin. Management J. 2006, 5, 337-350.

7. Zinatizadeh, A. A. L.; Mohamed, A. R.; Abdullah, A. Z.; Mashitah, M. D.; Hasnain Isa, M.; Najafpour, G. D.: Process Modeling and Analysis of Palm Oil Mill Effluent Treatment in an Up-Flow Anaerobic Sludge Fixed Film Bioreactor Using Response Surface Methodology (RSM). Water Res. 2006, 40, 3193-3208.

8. Yacob, S.; Ali Hassan, M.; Shirai, Y.; Wakisaka, M.; Subash, S.: Baseline Study of Methane Emission from Anaerobic Ponds of Palm Oil Mill Effluent Treatment. Sci. Total Environ., 2006, 366, 187-196.

9. Yacob, S.; Shirai, Y.; Ali Hassan, M.; Wakisaka, M.; Subash, S. Start-Up Operation of Semi-Commercial Closed Anaerobic Digester for Palm Oil Mill Effluent Treatment. Process Biochem. 2006, 41, 962-964.

10. Ariffin, A.; Shatat, Raid S. A.; Norulaini, A. R. N.; Omar, A. K. M.: Synthetic Polyelectrolytes of Varying Charge Densities But Similar Molar Mass Based on Acrylamide and their Applications on Palm Oil Mill Effluent Treatment. Desalination 2005, 173, 201-208.

11. Standard Methods for the Examination of Water and Wastewater, 20th ed.; American Public Health Association/American Water Association/Water Environment Federation: Washington, D.C., 1998.

12. Mollah, Y. A. M.; Morkovsky, P.; Gomes, A. G. J.; Kesmez, M.; Parga, J.; Cocke, D. L.: Fundamentals, Present and Future Perspectives of Electrocoagulation. J. Hazardous Mater. 2004, B114, 199-210.

13. Phutdhawong, W.; Chowwanapoonpohn, S.; Buddhasukh, D.: Electrocoagulation and Subsequent Recovery of Phenolic Compounds. Analytical Science. 2000, 16(10), 1083-1084.

14. Uğurlu, M.; Gürses, A.; Doğar, Ç.; Yalçın, M.: The removal of lignin and phenol from paper mill effluents by electrocoagulation. J. Environ. Mngt. In press (available online March 2007 in Science Direct).

15. Phutdhawong, W.; Buddhasukh, D.: Applications of Electrocoagulation; $1^{\text {st }}$ ed., Chotana Print Co. Ltd., Chiangmai, 2007, pp. 22-24. 